\title{
MINERAL RESOURCE POTENTIAL OF THE FOUR NOTCH ROADLESS AREA, WALKER COUNTY, TEXAS
}

\author{
By \\ B. B. Houser, U.S. Geological Survey \\ and \\ George S. Ryan, U.S. Bureau of Mines
}

\section{STUDIES RELATED TO WILDERNESS}

Under the provisions of the Wilderness Act (Public Law 88-577, September 3, 1964) and related acts, the U.S. Geological Survey and the U.S. Bureau of Mines have been conducting mineral surveys of wilderness and primitive areas. Areas officially designated as "wilderness," "wild," or "canoe" when the act was passed were incorporated into the National Wilderness Preservation System, and some of them are presently being studied. The act provided that areas under consideration for wilderness designation should be studied for suitability for incorporation into the Wilderness System. The mineral surveys constitute one aspect of the suitability studies. The act directs that the results of such surveys are to be made available to the public and be submitted to the President and the Congress. This report discusses the results of a mineral survey of the Four Notch Roadless Area (08133), Sam Houston National Forest, Walker County, Tex. The Four Notch Roadless Area was classified as a further planning area during the Second Roadless Area Review and Evaluation (RARE II) by the U.S. Forest Service, January 1979.

\section{MINERAL RESOURCE POTENTIAL SUMMARY STATEMENT}

The Four Notch Roadless Area is within the western Gulf of Mexico Coastal Plain and is underlain by Miocene and Pleistocene semiconsolidated clastic sedimentary rocks.

The area has moderate to high potential for oil and gas, as indicated by the regional geologic setting and the presence of nearby producing fields, although five dry holes have been drilled in the area and on private land enclosed by the area. Results of surface and shallow subsurface geologic studies, a radiometric survey, and geochemical and mineralogic studies of subsurface auger samples indicate that the roadless area has high potential for sand for construction and clay. Abundant clay and sand resources are presently available, however, much closer to population and industrial centers than those in the roadless area. There has been no mining or quarrying in the area.

\section{INTRODUCTION}

Location, Size, and Access

The Four Notch Roadless Area (fig. 1) comprises 5,605 acres in the Sam Houston National Forest, Walker County, Tex., about $70 \mathrm{mi}$ north of Houston. The roadless area is in the Gulf of Mexico Coastal Plain. It is characterized by low, rounded hills and has a total relief of about $170 \mathrm{ft}$ and median elevation of about $350 \mathrm{ft}$. The region is drained by a dendritic network of southeast-flowing intermittent streams tributary to the East Fork of the San Jacinto River. The humid subtropical climate has an annual precipitation of about $45 \mathrm{in}$. and a mean annual temperature of about $67^{\circ} \mathrm{F}$. The region supports the vegetation of the pine woods belt of the forested Coastal Plain.

Access to the periphery of the roadless area (fig. 2) is provided by named county roads (Three Notch Road and Four Notch Road) and by U.S. Forest Service road 200. Interior access is provided by U.S. Forest Service roads 213 and 223 , by a loop of the Lone Star foot trail, and by abandoned logging roads. Access to privately owned tracts of land, both entirely and partly enclosed by the area, is by unnumbered dirt roads that cross the roadless area.

\section{Previous Investigations}

The region was mapped previously at a scale of about $1: 125,000$ in a study of Walker County (Winslow, 1950) and at a scale of $1: 250,000$ as part of the Beaumont $1^{\circ} \times 2^{\circ}$ quadrangle of the "Geologic Atlas of Texas" (Barnes, 1968). The history and usage of the upper Cenozoic stratigraphic nomenclature has been summarized by Solis Iriarte (1981). The roadless area and vicinity have been covered in several reports of regional scope on mineral and energy resources. Walker County is included in the survey by Fisher and others (1965) of the rock and mineral resources of East 

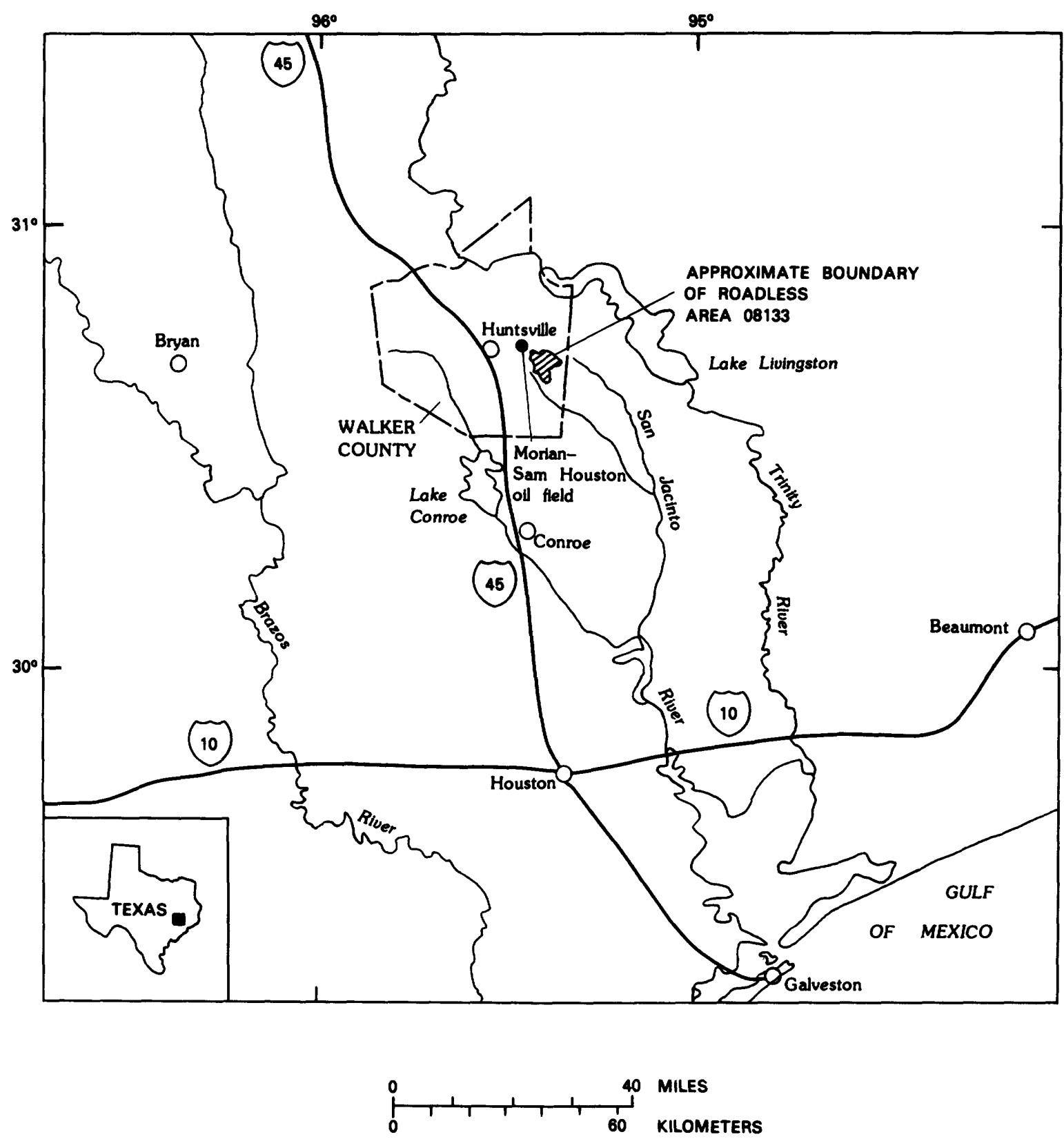

Figure 1.--Index map showing location of the Four Notch Roadless Area, Walker County, Tex. 


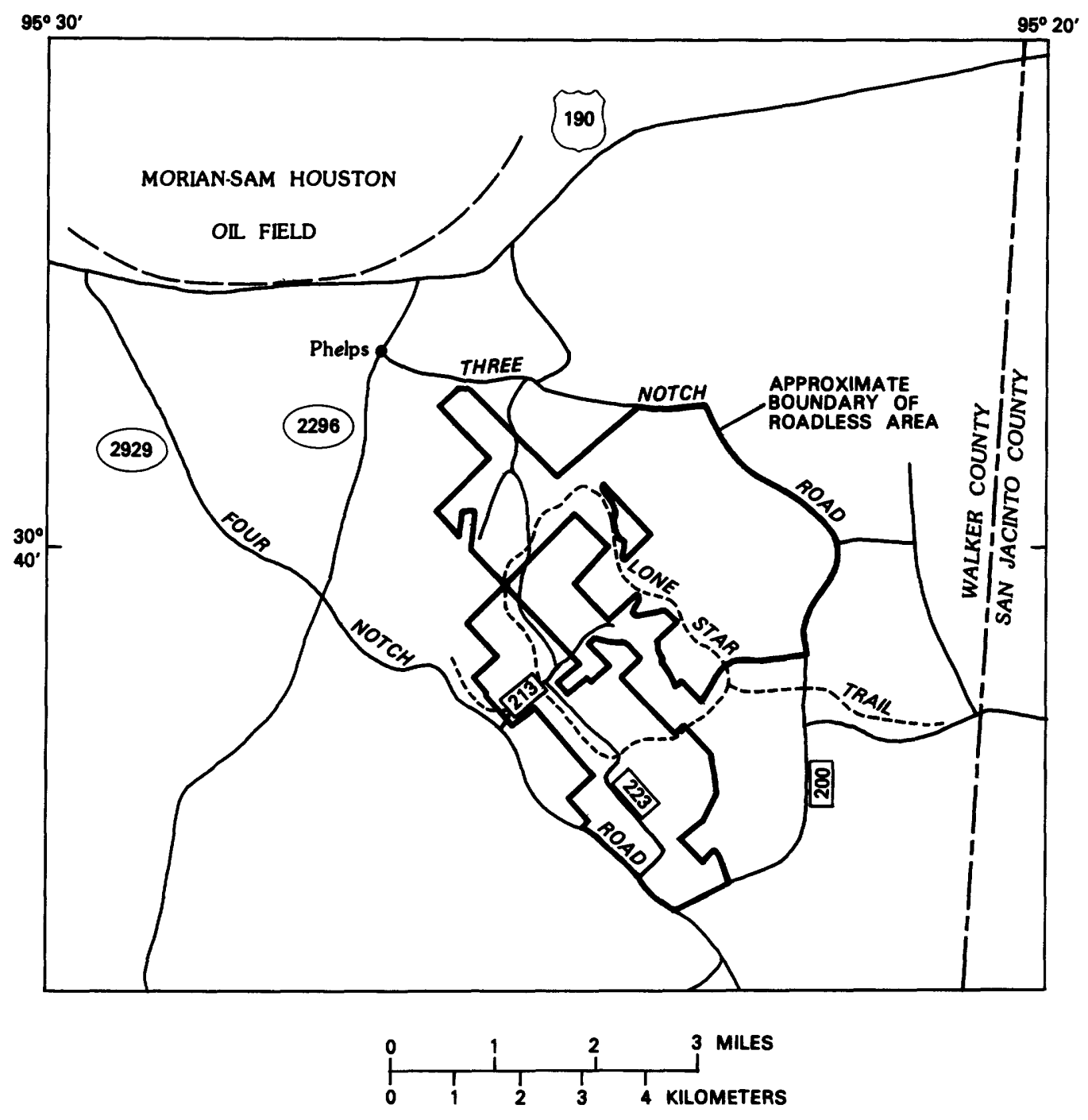

Figure 2.--Map showing access to the Four Notch Roadless Area and location of the Morian-Sam Houston oil field. 
Texas. Under the National Uranium Resource Evaluation (NURE) program, a reconnaissance geochemical survey for uranium was made of the Beaumont $1^{\circ} \times 2^{\circ}$ quadrangle, which includes the Four Notch Roadless Area (U.S. Department of Energy, 1980). Dickinson (1976) discussed the potential for uranium in the Gulf Coastal Plain in Texas. The ball-clay and bentonite resources of the central and western Gulf Coastal Plain were assessed by John Hosterman (written commun., 1982). Lignite resources in the national forests of Texas have been evaluated by Garner and others (1978); lignite resources in Texas as a whole have been evaluated by Kaiser and others (1980). Information on oil and gas production, reserves, and potential have been given by Cram (1971), PeppardSouders and Associates (1981, 1982), International Oil Scouts Association (1977), American Petroleum Institute, American Gas Association, and Canadian Petroleum Association (1980), St. Clair and others (1976), and Railroad Commission of Texas (1981).

\section{Present Investigation}

The U.S. Geological Survey conducted a geologic and geochemical survey of the region in January to March 1982, which included drilling and collecting samples for stratigraphic and geochemical analyses from 12 auger holes ranging from 17 to $87 \mathrm{ft}$ deep. The investigation by the U.S. Bureau of Mines, conducted in April 1981, included a radiometric survey and analysis of surface-sediment samples for uranium. The oil and gas resource potential of the roadless area was evaluated by Gordon L. Dolton using readily available data only.

\section{Surface and Mineral Ownership}

U.S. Forest Service records indicate that 99 percent of the mineral rights of the Four Notch Roadless Area are privately held. Permits for seismic exploration surveys in and around the roadless area are issued routinely.

\section{GEOLOGY}

The roadless area is in the north-central part of the greater western Gulf basin, which is filled with a thick sequence of fluvial, deltaic, and marine Cenozoic clastic rocks. This sequence overlies Cretaceous and Jurassic sandstones and carbonates and the Jurassic Louann Salt.

The region is underlain by upper Cenozoic semiconsolidated sediments that are partially covered by Quaternary alluvium. The oldest unit in the roadless area is the Miocene Fleming Formation. It consists chiefly of yellowish-gray, stiff, calcareous clay containing calcareous nodules as much as 1.5 in. across. Minor constituents are clayey fine sand and sandy clay.

The Pleistocene Willis Sand unconformably overlies the Fleming Formation. The Willis consists primarily of fine- to medium-grained, clean to muddy sand and lesser amounts of interbedded clayey sand, stiff sandy clay, and clay laminae. The contact between the Fleming and Willis is an erosional unconformity of low relief. It is marked by a 3- to 5-footthick oxidized zone consisting of red- and yellow- mottled clay at the top of the Fleming and local quartz-pebble gravel lenses less than $3 \mathrm{ft}$ thick at the base of the Willis.

Pleistocene(?) and Holocene alluvium is present in the flood plains and channels of the larger streams in and around the roadless area. The alluvium is lithologically similar to the Willis Sand and consists of fineto medium-grained sand and sandy clay containing local lenses of quartz-pebble gravel.

Within the roadless area, the sediments are undeformed. The strike of the unconformable surface separating the Fleming Formation and Willis Sand is about N. $80^{\circ}$ E. This surface slopes gently to the southeast at about $15 \mathrm{ft} / \mathrm{mi}$ in the southern part of the area and $30 \mathrm{ft} / \mathrm{mi}$ in the northern part of the area.

Data from an auger hole drilled $1.75 \mathrm{mi}$ north of the roadless area indicate about $100 \mathrm{ft}$ of stratigraphic offset in the contact of the Fleming with the Willis, down on the north. Four interpretations of this offset are shown in figure 3.

\section{ASSESSMENT OF MINERAL RESOURCE POTENTIAL}

\section{Oil and Gas}

The Four Notch Roadless Area has moderate to high potential for the discovery of oil and gas. In the western Gulf basin, which includes the roadless area and vicinity, oil and gas are produced from Jurassic through Pleistocene rocks. In the Tertiary part of this sequence, production tends to be localized by age in concentric, arcuate belts around the Gulf of Mexico, becoming progressively younger toward the center. One of these trends, the Jackson-Yegua (Eocene) trend, extends partly into the region of the Four Notch Roadless Area. Another, the deep Tuscaloosa trend (Cretaceous), also projects into the region south of the roadless area.

Sedimentary rocks of Eocene and Miocene age are exposed at the surface in the vicinity of the roadless area and regionally dip gently southward. In the subsurface, Tertiary rocks of Paleocene through Eocene age overlie Cretaceous rocks. Within the sequence, Eocene sandstone reservoirs of the Wilcox, Claiborne, and Jackson Groups and a variety of Cretaceous reservoirs account for significant oil and gas production. One of the largest salt-dome fields in Texas, the giant Conroe field, is only $20 \mathrm{mi}$ south of the Four Notch Roadless Area and has accounted for more than 600 million barrels of oil from Eocene and Oligocene rocks. Oil and gas production is associated with this and several other large salt domes in adjoining areas near the north margin of the Gulf Coast salt basin. In addition, production is associated with growth faults and folds that are locally related in part to elements of the Angelina-Caldwell flexure.

Production in the immediate vicinity of the roadless area is not large. It derives from reservoirs of Cretaceous and of Eocene age associated with faults and other structural elements. There is a history of exploration drilling in and around the roadless area, some of it quite deep (greater than 15,000 ft), but no significant production has been established in the immediate area. Closest production to the roadless area is to the west at the Morian-Sam Houston field (fig. 2), which has yielded approximately 150,000 barrels of oil from the Eocene Yegua Formation. This 

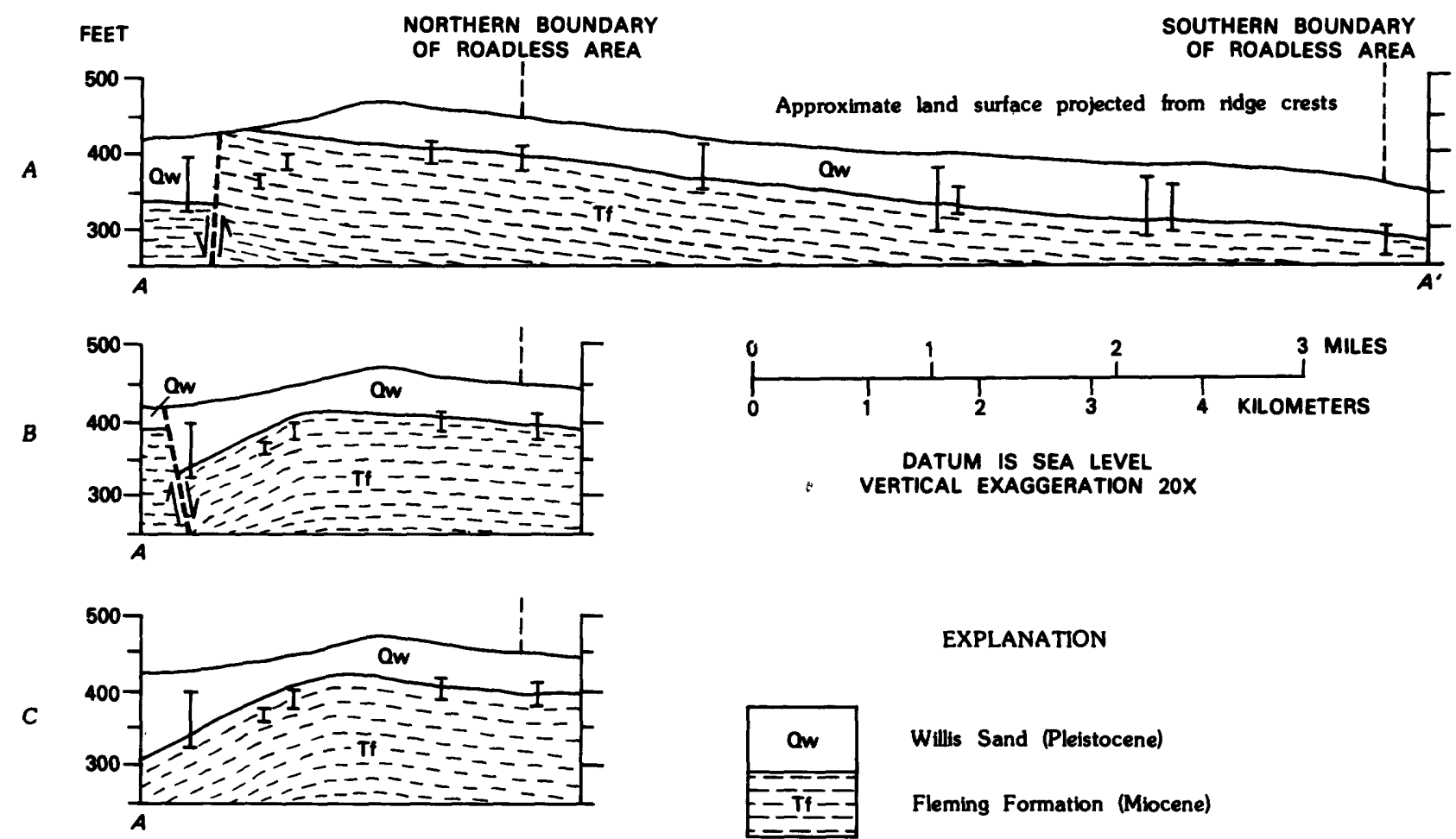

EXPLANATION

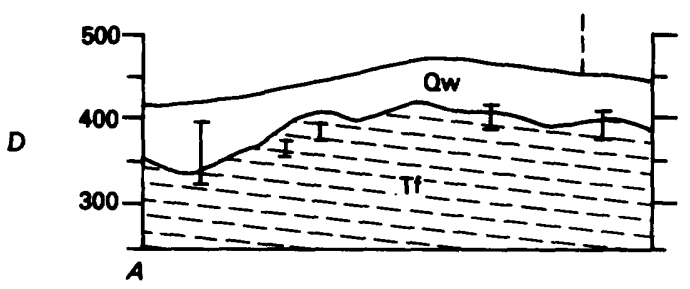

Willis Sand (Pleistocene)
Fleming Formation (Miocene)

Figure 3.--Cross sections showing (A) the FlemingWillis contact in the Four Notch Roadless Area, and $(A, B, C, D)$ four interpretations of the stratigraphic offset of this contact north of the area. Line of section ${\mathrm{A}-\mathrm{A}^{\prime}}^{\prime}$ shown in figure 4. 
field appears to be associated with a major fault trend. Other small fields, farther both to the north and to the south, are producing principally from Eocene and (or) Cretaceous rocks.

Four alternative interpretations of the stratigraphic offset of the Fleming-Willis contact north of the roadless area are shown in figure 3 . The potential for oil and gas in the northern part of the roadless area (fig. 4) is higher if the stratigraphic offset revealed there in the auger holes is caused by folding or faulting, rather than by pre-Willis erosion. It is not known if the trend of the offset is in any way related to the location of the Morian-Sam Houston field.

\section{Clay}

The calcareous clay of the Fleming Formation consists of major smectite, minor to zero kaolinite, and trace to zero illite. Although the clay is abundant and fairly free of sand, it apparently has no exceptional properties that are of value to industry.

Sand

The Willis Sand contains thick beds of relatively clean, moderately well sorted, fine- to mediumgrained sand that could be used in construction or for industrial purposes. There are no nearby markets, however, and similar sand is relatively abundant throughout the Texas Gulf Coastal Plain.

\section{Uranium}

A surface radiometric survey of the roadless area indicated anomalous radiation counts in two small areas. Samples collected from these two small areas contain only $9 \mathrm{ppm}$ and $26 \mathrm{ppm}$ of uranium. None of the subsurface auger samples show anomalous radiation counts. The NURE survey (U.S. Department of Energy, 1980 , p. 20) did not reveal any uranium deposits in the Beaumont $1^{\circ} \times 2^{\circ}$ quadrangle.

\section{Lignite}

Lignite is mined at the surface from Eocene rocks about $25 \mathrm{mi}$ north of the roadless area. Lignite occurs in the same Eocene formations beneath the roadless area, but it is too deep for surface mining. Garner and others $(1978$, p. 36$)$ reported that the shallowest lignite deposits in the Sam Houston National Forest are deeper than $1,500 \mathrm{ft}$ and range from 2 to $5 \mathrm{ft}$ thick.

\section{Trace-Element Abundance}

Nineteen auger samples of clay from the Fleming Formation and Willis Sand were analyzed spectrographically for 31 minor and trace elements. Table 1 shows the concentrations of 14 trace elements in Fleming and Willis clay in comparison with the concentrations of these elements in chiefly fine grained rocks of the Pierre Shale (Schultz and others, 1980). This comparison indicates that the trace-element composition of the clay in the roadless area is within the normal range for nonmineralized clay sediment, both marine and nonmarine.
Table 1.--Average trace-element camposition of 19 samples of clay from the Willis Sand and Fleming Formation and 202 samples from the Pierre Shale (Schultz and others, 1980)

[Al] values in parts per million; six-step semiquantitative spectrographic analyses made in U.S. Geological Survey laboratories; analyses by Betty Adrian]

\begin{tabular}{|c|c|c|c|c|}
\hline \multirow{2}{*}{$\begin{array}{r}\text { Trace } \\
\text { ele- } \\
\text { ments }\end{array}$} & \multicolumn{2}{|c|}{$\begin{array}{l}\text { Willis Sand and } \\
\text { Fleming Formation }\end{array}$} & \multicolumn{2}{|c|}{ Pierre Shale } \\
\hline & $\underset{\text { mean }}{\text { Ar i thmet ic }}$ & $\begin{array}{l}\text { Standard } \\
\text { deviation }\end{array}$ & $\underset{\text { mean }}{\text { Arithmet ic }}$ & $\begin{array}{l}\text { Standard } \\
\text { deviation }\end{array}$ \\
\hline Mn--- & 624 & 418 & 720 & 275 \\
\hline B---- & 96 & 18 & 99 & 49 \\
\hline $\mathrm{Ba}---$ & 758 & 533 & 650 & 300 \\
\hline Co--- & 15 & 6 & 12 & 6 \\
\hline Cr--- & 86 & 36 & 75 & 34 \\
\hline $\mathrm{Cu}---$ & 28 & 13 & 34 & 23 \\
\hline La--- & 60 & 17 & 39 & 25 \\
\hline $\mathrm{Ni}---$ & 35 & 17 & 36 & 27 \\
\hline $\mathrm{Pb}---$ & 38 & 19 & 22 & 8 \\
\hline Sc--- & 12 & 5 & 16 & 5 \\
\hline Sr--- & 200 & 66 & 204 & 204 \\
\hline V---- & 121 & 45 & 156 & 97 \\
\hline Y-- - & 40 & 19 & 28 & 12 \\
\hline $\mathrm{Zr}---$ & 174 & 65 & 190 & 62 \\
\hline
\end{tabular}

\section{REFERENCES CITED}

American Petroleum Institute, American Gas Association, and Canadian Petroleum Association, 1980, Reserves of crude oil, natural gas liquids, and natural gas in the United States and Canada as of December 31, 1979: New York, American Petroleum Institute, v. 34, $253 \mathrm{p}$.

Barnes, V. E., 1968, Geologic atlas of Texas, Beaumont $1^{\circ} \times 2^{\circ}$ quadrangle: University of Texas at Austin, Bureau of Economic Geology, scale $1: 250,000$.

Cram, I. H., ed., 1971, Future petroleum provinces of the United States-their geology and potential: American Association of Petroleum Geologists Memoir 15, v. 2, p. 805-984.

Dickinson, K. A., 1976, Uranium potential of the Texas Coastal Plain: Geological Society of America Abstracts with Programs, v. 8, no. 1, p. 18.

Fisher, W. L., Chelf, C. R., Shelby, C. A., Garner, L. E., Owen, D. E., and Schofield, D. A., 1965, Rock and mineral resources of East Texas: University of Texas at Austin, Bureau of Economic Geology Report of Investigatons No. 54, 439 p.

Garner, L. E., Pass, D. A., and West, E. S., 1978, Evaluation of lignite resources in the National Forests of Texas: Unpublished data on file at U.S. Forest Service office, Lufkin, Tex. [report prepared by University of Texas at Austin, Bureau of Economic Geology, contract no. 38$3145], 82 \mathrm{p}$.

International Oil Scouts Association, 1977, International oil and gas development yearbook 1977 (Review of 1976): International Oil Scouts Association, Austin, Tex., v. 47, pt. 2, 352 p. 


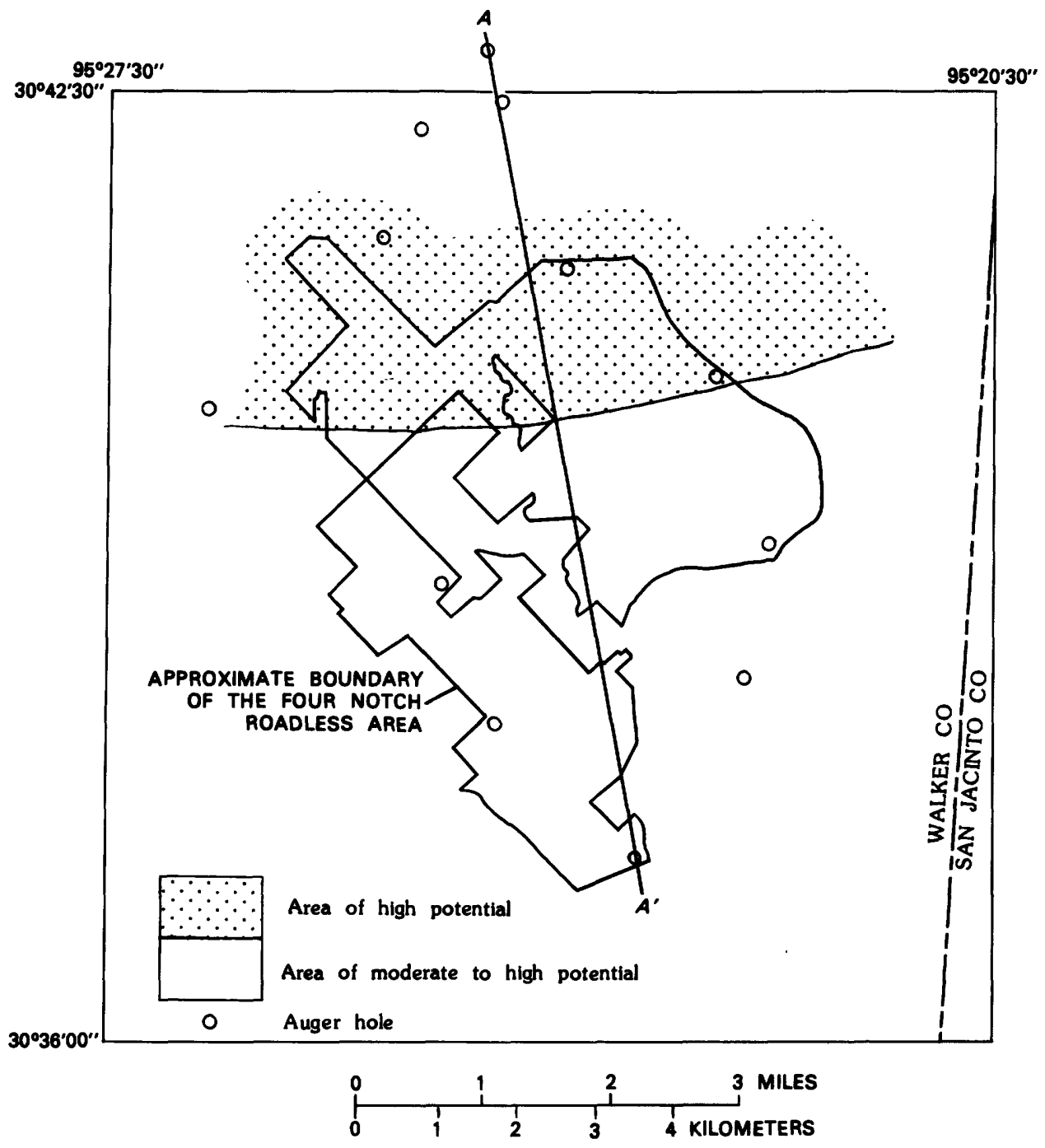

Figure 4.--Map showing resource potential for oil and gas in the Four Notch Roadless Area, Walker County, Tex. 
Kaiser, W. R., Ayers, W. B., Jr., and LaBrie, L. W., 1980, Lignite resources in Texas: University of Texas at Austin, Bureau of Economic Geology Report of Investigations No. 104, 52 p.

Peppard-Souders and Associates, 1981, Executive reference map no. 302 for East Texas: Dallas, Tex., Geomap, scale 1:187,500.

1982, Executive reference map no. 312 for northeast Texas Gulf Coast: Dallas, Tex., Geomap, scale 1:187,500.

Railroad Commission of Texas, 1981, Annual report of the Oil and Gas Division: Austin, Tex., 700 p.

St. Clair, A. E., Evans, T. J., and Garner, L. E., compilers, 1976, Energy resources of Texas (reprinted 1981): Austin, Tex., University of Texas, Bureau of Economic Geology, scale $1: 1,000,000$.

Schultz, L. G., Tourtelot, H. A., Gill, J. R., and Boerngen, J. G., 1980, Composition and properties of the Pierre Shale and equivalent rocks, northern Great Plains region: U.S. Geological Survey Professional Paper 1064-B, $114 \mathrm{p}$.
Solis Iriarte, R. F., 1981, Upper Tertiary and Quaternary depositional systems, central Coastal Plain, Texas-regional geology of the coastal aquifer and potential liquid-waste repositories: University of Texas at Austin, Bureau of Economic Geology Report of Investigatons No. $108,89 \mathrm{p}$.

U.S. Department of Energy, 1980, Hydrogeochemical and stream sediment basic data for Beaumont NTMS quadrangle, Texas: National Uranium Resource Evaluation Project GJBX-67 (80), 131 p.

Winslow, A. G., 1950, Geology and ground-water resources of Walker County, Texas: Texas Board of Water Engineers Bulletin 5003, 48 p. 